\title{
Palaeomagnetic results from the Lopra-1/1A re-entry well, Faroe Islands
}

\author{
Niels Abrahamsen
}

The palaeomagnetic dating and evolution of the Faroe Islands are discussed in the context of new density and rock magnetic results from the deepened Lopra-1/1A well. The reversal chronology of the c. $61 / 2 \mathrm{~km}$ thick basalt succession is also described. The polarity record of the Faroe Islands may now be correlated in detail with the Geomagnetic Polarity Time Scale. The lowermost (hidden) part of the lower basalt formation correlates with Chron C26r (Selandian age), the top (exposed) part of the lower basalt formation correlates with Chrons C26n, C25r and C25n (Selandian and Thanetian age) and the middle and upper basalt formations correlate with Chron C24n.3r (Ypresian). Inclinations indicate a far-sided position of the palaeomagnetic poles, which is characteristic of results from most Palaeogene volcanics from the northern North Atlantic region.

The density, magnetic susceptibility and magnetic remanence of 20 specimens from one solid core (11/2 $\mathrm{m}$ in length) and 26 sidewall cores from the well between -2219 and $-3531 \mathrm{~m}$ below sea level (b.s.l.) suggest that the volcanic materials can be divided into two characteristic groups: solid unaltered basalts and altered basalts and tuffs. The magnetic properties are typically log-normally distributed and the carriers of remanence are Ti-poor Ti-magnetites with Curie temperatures close to $580^{\circ} \mathrm{C}$. The inclination of the $1 \frac{1}{2} \mathrm{~m}$ core at $2380 \mathrm{~m}$ b.s.l. is dominantly negative (two plugs at the very top of the core do show normal polarity, but they are likely to be misoriented as all specimens appear to be from one flow). Magnetic logging (magnetic susceptibility and field intensity) down to $3515 \mathrm{~m}$ b.s.l. was made in Lopra-1/1A together with other geophysical logs but did not yield conclusive inclination data.

Keywords: Palaeomagnetism, rock magnetism, magnetic reversals, plate tectonics, Faroe Islands, Lopra-1/1A well, North Atlantic, large igneous province

Department of Earth Sciences, University of Aarhus, Finlandsgade 8, DK-8200 Aarhus N, Denmark.

E-mail: Abraham@geo.au.dk

\section{Review of the geology}

The Faroe Islands are situated on the eastern side of the northern North Atlantic between the Shetland Islands and Iceland on the northern part of the NE-SW-trending elongated Faroe Rise (Fig. 1). The volcanic islands are a result of the hotspot-related plume activity recorded by the BritoArctic Large Igneous Province (LIP) (Lawver \& Muller 1994; Larsen \& Saunders 1998; T.B. Larsen et al. 1999; Burke \& Torsvik 2004) that stretches from present-daycentral West Greenland to the north-western parts of the UK.
Seismic (e.g. Richardson et al. 1998) and gravity investigations (e.g. Saxov \& Abrahamsen 1964) suggest that the invisible basement of the islands is composed of continental lithospheric crust, somewhat thinned by lithospheric stretching processes during the continental breakup that formed the North Atlantic.

The exposed part of the Faroe Islands is composed of a c. $3 \mathrm{~km}$ thick pile of Palaeogene flood basalts (Rasmussen \& Noe-Nygaard 1969, 1970; Noe-Nygaard \& Rasmussen 1984) situated above a c. $3 \frac{1 / 2}{\mathrm{~km}}$ unexposed volcanic sequence below sea level (Fig. 2). Only minor sedimenta- 


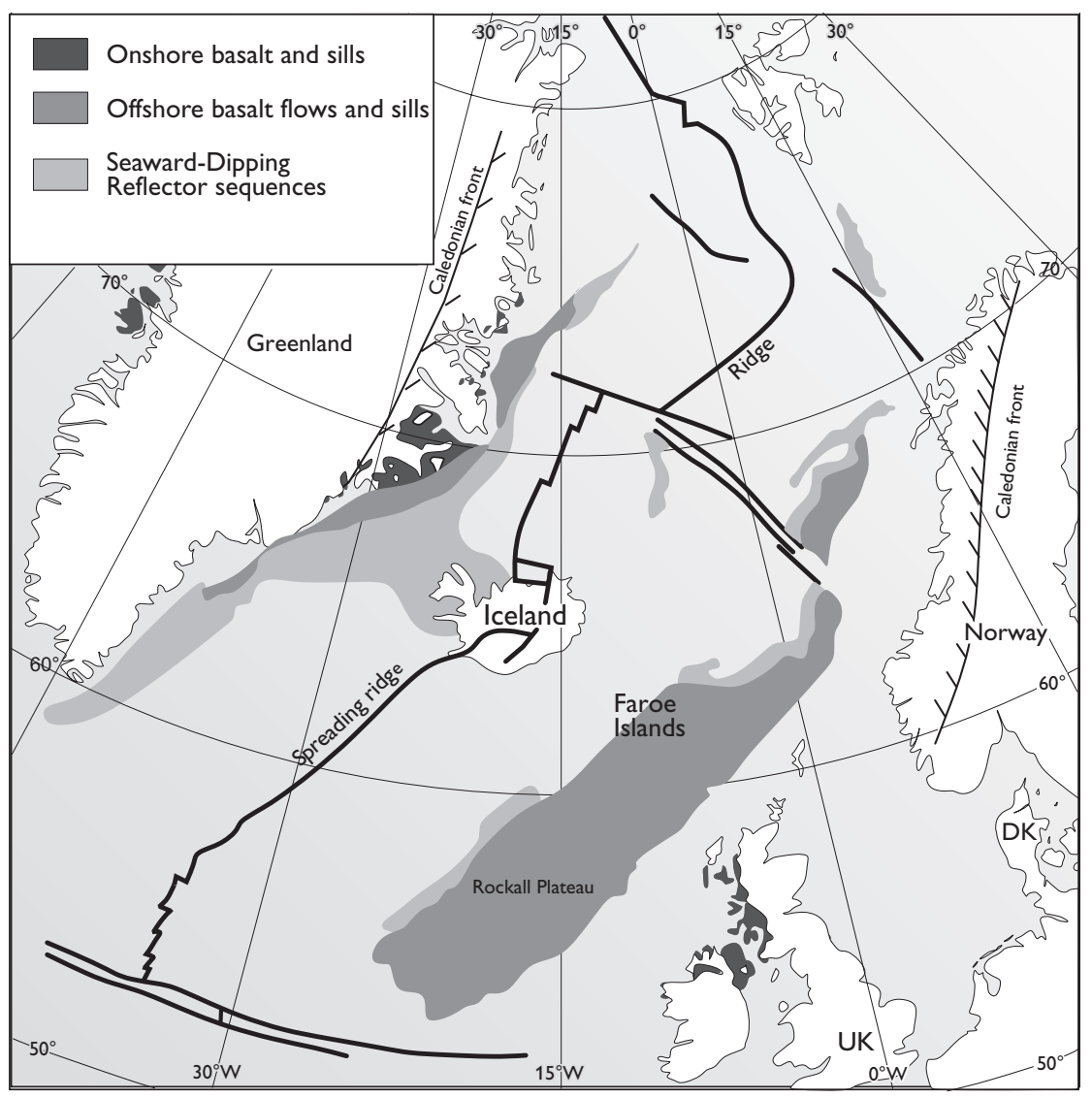

Fig. 1. Index map of the eastern North Atlantic showing the Faroe Islands (modified from Larsen et al. 1995).

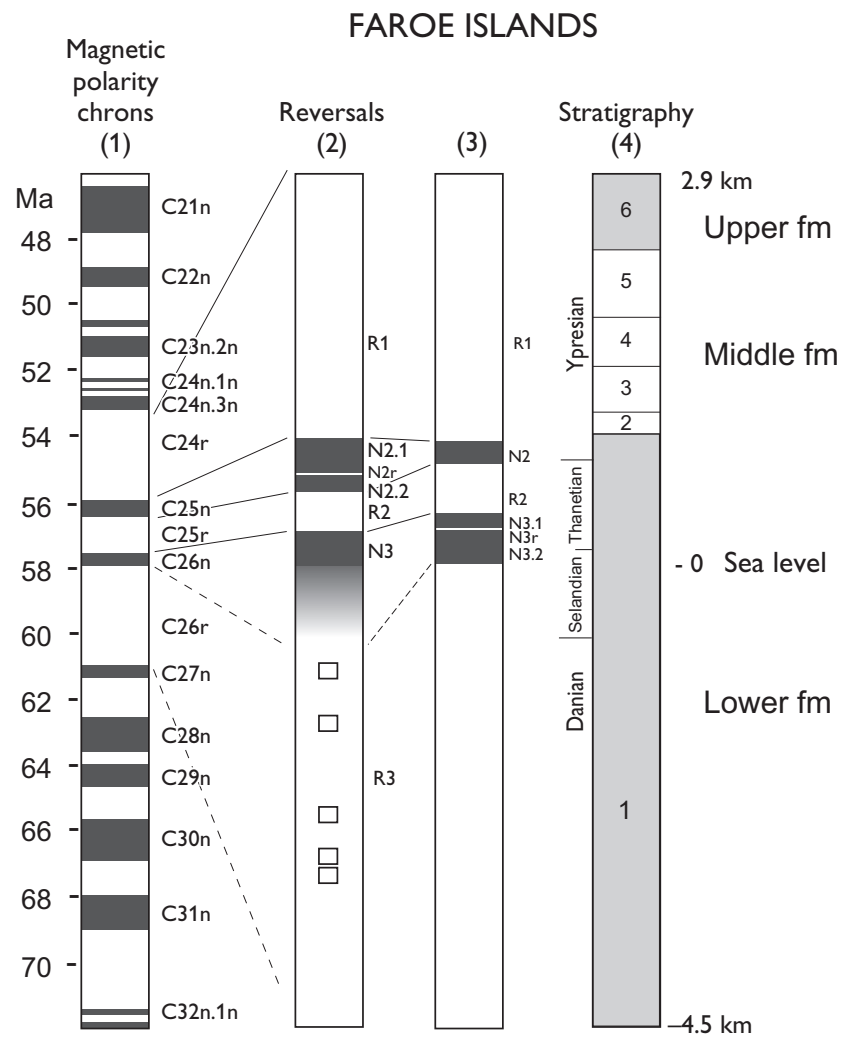

ry layers are intercalated in the whole volcanic sequence.

The volcanic sequence, more than $6 \frac{1}{2} \mathrm{~km}$ in total thickness (Waagstein 1988; L.M. Larsen et al. 1999), is divided into three parts, the lower ( $>4 \frac{1}{2} \mathrm{~km}$ thick), the middle $(1.4 \mathrm{~km}$ thick) and the upper basalt $(>0.9 \mathrm{~km}$ thick) formations. The basalts are cut by numerous dykes and a few sills. An up to $10 \mathrm{~m}$ thick coal-bearing formation of lacustrine claystones and shales was deposited on top of the slightly eroded surface of the lower basalt formation (the A-level). Two other stratigraphical levels, B (in the middle formation) and $\mathrm{C}$ (separating the middle and upper formations), are also useful for stratigraphical purposes (Fig. 2).

The purpose of the present contribution is to present

Fig. 2. Compilation of magnetic reversals within the $c .61 \frac{1}{2} \mathrm{~km}$ thick basalt pile of the Faroe Islands, showing stratigraphy and the correlation with the Geomagnetic Polarity Time Scale. The four columns are based upon information compiled from: (1) Ogg (1995); (2) Abrahamsen (1965, 1967), Abrahamsen et al. (1984), Waagstein (1988) and Riisager et al. 2002a; (3) Tarling \& Gale (1968); (4) Rasmussen \& Noe-Nygaard (1970), Waagstein (1988) and L.M. Larsen et al. (1999). 
Table 1. Palaeomagnetic results from the Faroe Islands

\begin{tabular}{|c|c|c|c|c|c|c|c|c|c|c|c|c|c|}
\hline Formation/site/core depth & $\mathrm{N}(\mathrm{Dg})$ & Decl & $\begin{array}{c}\text { Incl } \\
\circ\end{array}$ & $\alpha_{95}$ & k & $\begin{array}{l}\text { Plat } \\
{ }^{\circ} \mathrm{N}\end{array}$ & $\begin{array}{l}\text { Plon } \\
{ }^{\circ} \mathrm{E}\end{array}$ & $\delta_{\substack{95 \\
0}}$ & $\begin{array}{c}\mathrm{A}_{95} \\
0\end{array}$ & $\begin{array}{l}\text { Palaeo- } \\
\text { lat }\left({ }^{\circ} \mathrm{N}\right)\end{array}$ & No. & Polarity & Reference \\
\hline All formations & 33 & 176.0 & \pm 69.0 & 6 & 14 & 80.0 & 159.0 & 10.3 & & 52.5 & 1 & R\&N & (1) \\
\hline All formations & 1809 & 185.0 & \pm 66.4 & 1.9 & & 76.7 & 161.0 & 3.1 & & 48.9 & 2 & R\&N & (2) \\
\hline ubf, Torshavn & 34 & 171.9 & -72.2 & 3.5 & 53 & 84.0 & 218.0 & 6.3 & & 57.3 & 3 & $\mathrm{R}$ & (3) \\
\hline ubf, Argir & 8 & 175.1 & $-53.9^{*}$ & 2.2 & 258 & 62.3 & 182.4 & 3.1 & & $34.4^{*}$ & * & $\mathrm{R}$ & (3) \\
\hline mbf, Argisfossar & 18 & 156.0 & $-36.0^{*}$ & & & 48 & & & & $20.0 *$ & $*$ & $\mathrm{R}$ & (4) \\
\hline mbf, Vestmanna core & 275 & & -61.8 & 1.2 & 53.4 & 70.8 & & 1.9 & & 43.0 & 4 & $\mathrm{R}$ & (5) \\
\hline Ibf, Vestmanna core & 28 & & \pm 63.4 & 6.3 & 19.4 & 72.8 & & 10.0 & & 45.0 & 5 & R\&N & (5) \\
\hline $\mathrm{mbf}+\mathrm{lbf}$, Vestm. core & 303 & & $\pm 61.9 *$ & 1.2 & 46.1 & 70.9 & & 1.9 & & $43.1 *$ & $*$ & R\&N & (5) \\
\hline$m b f+l b f$ & $548(43)$ & 7.7 & \pm 60.9 & 4.5 & 24.5 & 71.4 & 154.7 & & 6.0 & 41.9 & 6 & R\&N & (6) \\
\hline Ibf, Lopra-1; 862 mbf & 6 & & -75.0 & 1 & & & & & & 61.8 & 7 & $\mathrm{R}$ & (7) \\
\hline lbf, Lopra-1; 1219 mbf & 8 & & -62.0 & & & & & & & 43.2 & 8 & ?R & (7) \\
\hline Ibf, Lopra-1; 1923 mbf & 5 & & -73.0 & 3 & & & & & & 58.6 & 9 & $\mathrm{R}$ & (7) \\
\hline Ibf, Lopra-1; 2178 mbf & 7 & & $-55.0^{*}$ & & & & & & & $35.5^{*}$ & $*$ & ?R & (7) \\
\hline Ibf, Lopra-1A; 2380 mbf & 20 & & -71.7 & 2.0 & 709 & & & & & 56.5 & 10 & $\mathrm{R}$ & (8) \\
\hline Average, Nos $1-10$, except $*$ & (10) & & \pm 67.2 & 1.4 & & & & & & 50.0 & 11 & R\&N & (8) \\
\hline Average, Nos 1, 2, $3 \& 6$ & (4) & 181.2 & \pm 67.3 & 6.3 & 213 & 78.7 & 164.4 & & 8.0 & 50.1 & 12 & R\&N & (8) \\
\hline
\end{tabular}

Ibf, mbf, ubf: lower, middle and upper basalt formations; No.: number in palaeolatitude figure; * Not used in average; N: number of samples; Dg: directional groups; Decl: mean of cleaned declination; Incl: mean of cleaned inclination; $\alpha_{95}$ : cone of $95 \%$ confidence. For core data the inclination statistics of Kono (1980) were used for $k$ and $\alpha_{95}$ (Tarling 1983); k: Fisher precision parameter; Plat: latitude of apparent palaeomagnetic pole; Plon: longitude of apparent palaeomagnetic pole; $\delta_{95}$ and $A_{95}$ : error angles of app. latitude and app. palaeopole at $95 \%$ confidence level; (1) Abrahamsen 1967; (2) Tarling 1970; (3) Løvlie \& Kvingedahl 1975; (4) Løvlie 1975; (5) Abrahamsen et al. 1984; (6) Riisager et al. 2002a; (7) Schönharting \& Abrahamsen 1984; (8) This work.

the magnetic results from a core of basaltic rock obtained from the Lopra-1/1A reentry well and to discuss these data in relation to other palaeomagnetic results from the Faroe Islands.

\section{Previous work}

Magnetic investigations in relation to the Faroe Islands have been made since the early 1960s (Abrahamsen 1965, 1967; Saxov \& Abrahamsen 1966; Tarling \& Gale 1968; Tarling 1970; Schrøder 1971; Løvlie 1975; Løvlie \& Kvingedal 1975; Abrahamsen et al.1984; Schönharting \& Abrahamsen 1984; Tarling et al. 1988). Density determinations (Saxov \& Abrahamsen 1964) as well as gravity measurements (Saxov 1969) and seismic investigations (Pálmason 1965; Bott et al. 1974, 1976; Casten 1974; Nielsen et al. 1981; Richardson et al. 1998) have been made on and around the islands. Geophysical logs from the Lopra-1/1A and Vestmanna-1 boreholes have been published by Nielsen et al. (1984), Boldreel (2006, this volume) and Abrahamsen \& Waagstein (2006, this volume). Geothermal measurements were described by Balling et al. (1984) and Balling et al. (2006, this volume).

Palaeomagnetic results from the Faroe Islands have been published by Abrahamsen $(1965,1967)$, Tarling \& Gale (1968), Tarling (1970), Løvlie (1975), Løvlie \& Kvingedal (1975), Abrahamsen et al. (1984), Schönharting \& Abrahamsen (1984) and Riisager et al. (2002a, b). A comparison of palaeomagnetic results from East Greenland and other results from the Palaeogene of the North Atlantic Igneous Province (NAIP) was published by Tarling et al. (1988) and a critical review of palaeomagnetic poles from the Eurasian part of the NAIP together with a new pole for the Faroe Islands was presented by Riisager $e t$ al. (2002a). A summary of all published palaeomagnetic directional data from the Faroe Islands is shown in Table 1.

The magnetic results for the exposed part of the basalt succession were extended by the wells at Vestmanna- 1 and Lopra-1 in 1980-1981 (Abrahamsen et al. 1984; Schönharting \& Abrahamsen 1984) and by the re-entry of the Lopra-1/1A hole in 1996, the results of which are presented in this paper. Despite intentions, the re-entry hole at Lopra-1/1A reached a depth of $3565 \mathrm{~m}$ without penetrating to the base of the lower basalt formation volcanics.

The polarity sequence and the compiled total stratigraphic column of the Faroe Islands as now known are shown in Fig. 2, together with the Geomagnetic Polarity Time Scale (GPTS). Essentially we find three intervals of reverse magnetic polarity (R1, R2, R3) with two normal 


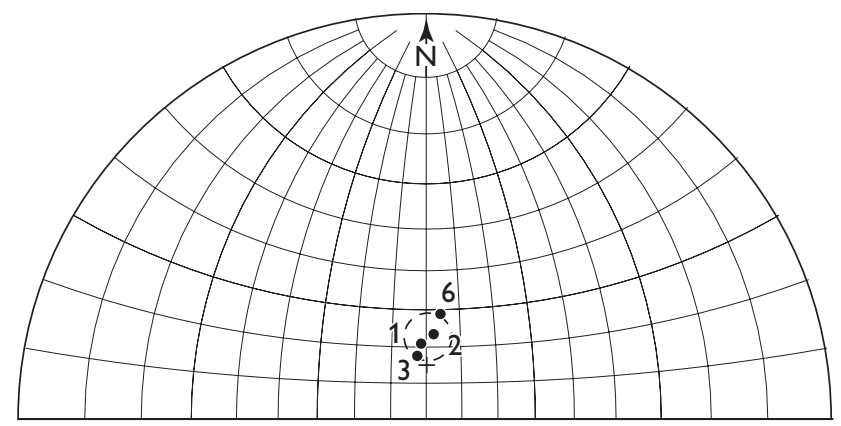

Fig. 3. Palaeomagnetic directions from the Faroe Islands (from Table 1, results Nos 1, 2, 3 and 6) with $\alpha_{95}$ circle. The axial dipole field direction is indicated by a cross.

polarity intervals in between (N2 and N3). Minor differences between columns (2) and (3) in Fig. 2 are likely to be due to somewhat different positions of the profiles investigated on Suðuroy, the southernmost of the Faroe Islands.

According to recent high-precision ${ }^{40} \mathrm{Ar}-{ }^{39} \mathrm{Ar}$ datings (Storey et al. 1996; L.M. Larsen et al. 1999), the basalt formations in the Faroe Islands as well as the contemporaneous East Greenland basalts can be divided into an older part with ages of about 59-56 Ma, followed (after a pause or a period with much reduced volcanic activity) by a younger part, with ages of 56-55.5 Ma for the Faroes and 5654.5 for East Greenland.

Based upon these radiometric datings, the polarity record of the Faroe Islands may now be correlated to the GPTS as shown in Fig. 2. The lowermost (hidden) part of the lower basalt formation correlates with Chron C26r (Selandian age), the upper (exposed) part of the lower basalt formation correlates with Chrons C26n, C25r and C25n (Selandian and Thanetian) and the middle and upper basalt formations correlate with Chron C24r (Ypresian). This correlation follows the suggestion by Waagstein (1988), who revised the original interpretation of Abrahamsen et al. (1984) by suggesting that R3 belongs to Chron C26r rather than to C24r. More details in relation to magnetic inclinations from the Lopra-1/1A data are discussed below.

Assuming the geomagnetic field to have been a central, axial dipole field, the palaeolatitude may be determined from the characteristic (primary) inclination of the volcanics, combining both polarities. A compilation of all inclination values obtained from the Faroe Islands is listed in Table 1. Using inclination statistics (Kono 1980; Tarling 1983) the fisherian mean of published inclinations (group numbers $1-10$, Table 1 ) is $67.2^{\circ} \pm 1.4^{\circ}$ (equivalent to a palaeolatitude of $50.0^{\circ} \pm 2.1^{\circ}$ ), whereas the average of the palaeolatitudes listed is $50.9^{\circ} \pm 2.3^{\circ}( \pm 1$

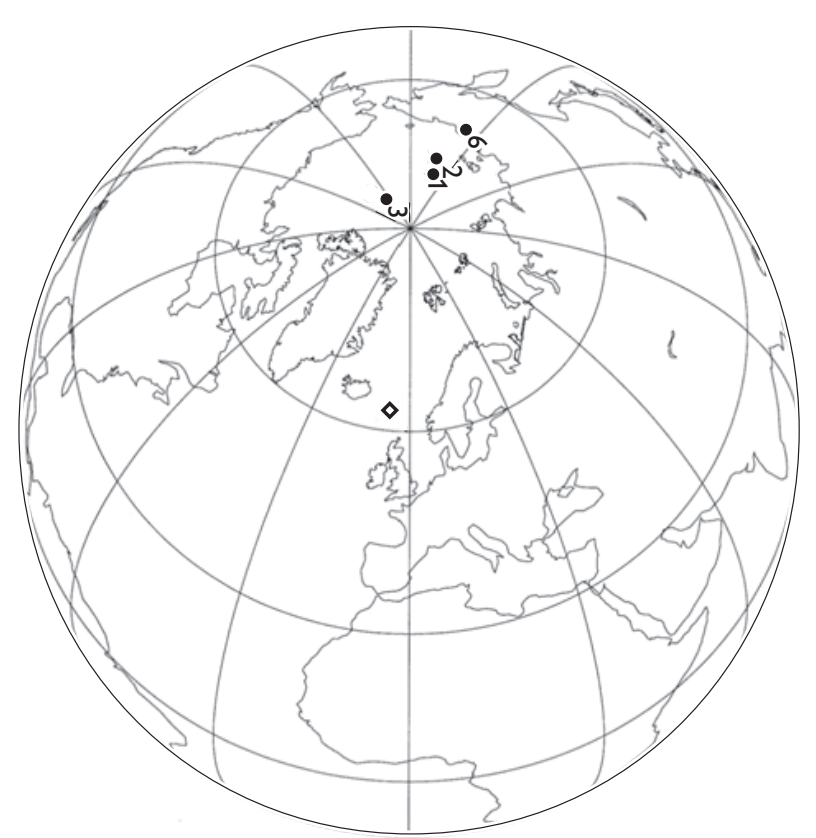

Fig. 4. Apparent palaeomagnetic pole positions (solid circles) with 95\% significance circle (Table 1, poles Nos 1, 2, 3 and 6). All poles appear 'farsided' as seen from the Faroe Islands (diamond). Further discussion in the text.

sigma). Further discussion of the shallow inclinations and the palaeolatitude question will be given below.

\section{Palaeogeography}

Many palaeogeographic reconstructions of the North Atlantic have been published since the early work of Bullard et al. (1965) (e.g. Ziegler 1990; Knott et al. 1993; L.M. Larsen et al. 1999; Torsvik et al. 2001; Mosar et al. 2002). Before about $60 \mathrm{Ma}$, the supposed mantle hotspot (just south-east of Iceland at the present day) lay under the volcanic areas of Disko and Nuussuaq in West Greenland (O'Connor et al. 2000; Nielsen et al. 2002; Chambers et al. 2005), far from the Faroe Islands that are situated just north-west of the continental margin of Europe. The whole volcanic pile of the Faroe Islands, more than $6 \frac{1}{2} \mathrm{~km}$ thick, was formed in the time interval between Chron $26(61.65$ $\mathrm{Ma}$ ) and Chron 24n.3n (c. 53.286 Ma) (Chron ages are the orbitally tuned age calibration of Gradstein et al. 2004, table 5.2). During this time interval, the hotspot moved eastwards under Greenland as Greenland moved westnorth-west relative to Europe and the North Atlantic gradually opened between the Faroe Islands and Greenland.

Absolute declinations are known from only four of the palaeomagnetic investigations from the Faroe Islands (Ta- 


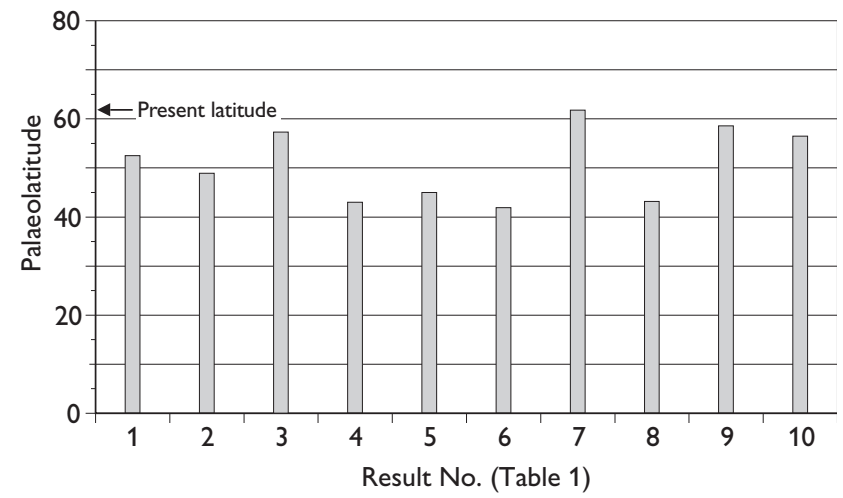

Fig. 5. Histogram of apparent palaeolatitudes according to Table 1 (poles Nos 1-10). Most results appear systematically low compared to the present-day latitude. For further discussion see the text.

ble 1, Nos 1, 2, 3 and 6). If both normal and reverse polarities are combined and assumed to be normal directions towards the north with steep down-dip (positive) inclinations, the four directions appear as shown in Fig. 3. The equivalent apparent palaeomagnetic pole positions are shown in Fig. 4. All four poles are seen to be 'farsided' (Wilson 1971; Merrill et al. 1998), the apparent palaeomagnetic poles falling beyond the geographic pole as seen from the Faroe Islands. An equivalent histogram of all published apparent palaeolatitudes (Table 1) is also illustrated in Fig. 5, most of which show low values as compared to the present-day latitude.

\section{Lopra-1/1A investigations}

\section{Sampling, instruments and techniques used}

The material investigated from the extended Lopra-1/1A well consists of two types: core plugs from the solid core ( 2380.0 to $2381.3 \mathrm{~m}$ ) and sidewall cores (between 2219 and $3531 \mathrm{~m}$ ). The solid core is $1.4 \mathrm{~m}$ long and in several pieces, but some fit together, as shown in Fig. 6. After marking the core with an upward directed arrow in the core lab at GEUS, 20 plugs with a diameter of $2.5 \mathrm{~cm}$ were drilled orthogonal to the main core and cut to a standard length of $2.2 \mathrm{~cm}$. The major part of the present magnetic investigation is concentrated upon these 20 plugs. In addition some rotary sidewall cores were investigated. The pieces from the sidewall cores had a diameter of 2.33 $\mathrm{cm}$ and varied in length, which limited the possibility of fitting these samples into the magnetic instrument holders.

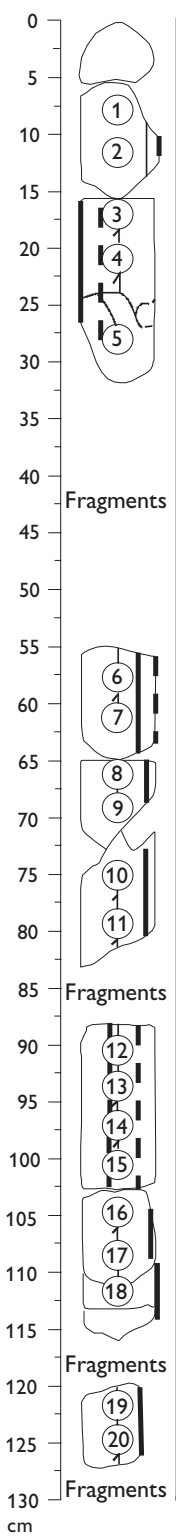

Fig. 6. Sketch from a photograph of the Lopra-1/1A core between 2380 and $2381.4 \mathrm{~m}$. The fragments containing the numbered 1inch core plugs are indicated. The absolute azimuths of the individual segments and fragments are not known. The top segment containing plugs Nos 1 and 2 appears to have been turned upsidedown before the core was archived.

\section{Bulk density}

To avoid problems with air bubbles adhering to the relatively small specimens if they were weighted in water, the bulk density was determined by weighing in air only (to an accuracy of $\pm 0.001 \mathrm{~g}$ ), then determining the volume by measuring the shape of the specimens (to an accuracy of $\pm 0.02 \mathrm{~cm}$ ). The likely accuracy in the finally determined density is about $\pm 2-3 \%$, depending on the rough- 
Table 2a. Lopra-1/1A: magnetic susceptibility, NRM, Q-ratio, density Solid core $(\mathrm{d}=25 \mathrm{~mm})$

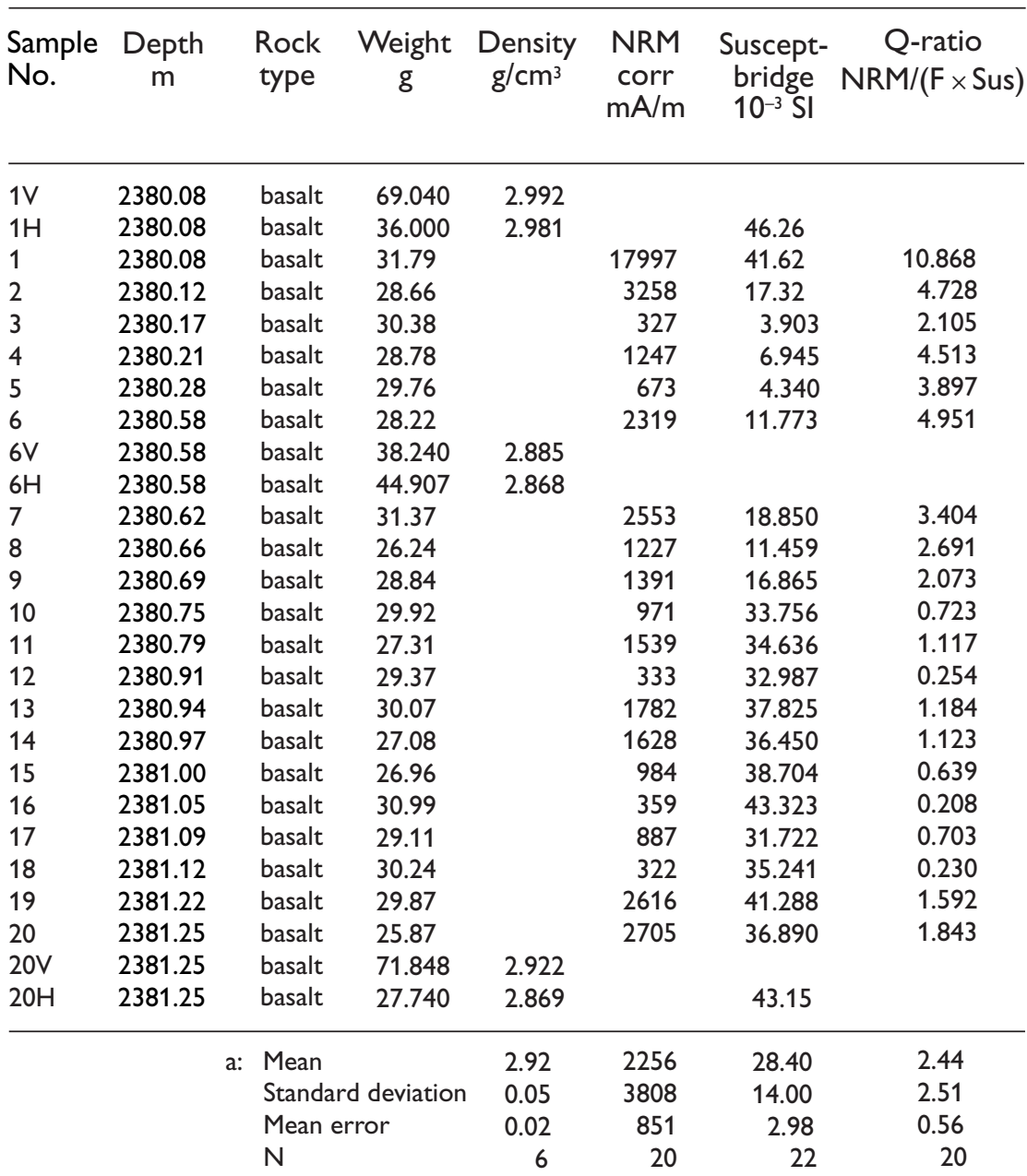

ness of the shape. A total of 34 specimens were determined (Table 2).

\section{Susceptibility}

Two types of susceptibility instruments were used. Initial whole core measurements were made by a handheld Czech kappameter KT5 (sensitivity \pm 0.00001 SI) before drilling plugs from the core. A Molspin bulk susceptibility bridge (sensitivity $\pm 0.000001 \mathrm{SI}$ ) was then used to measure the susceptibility of the core plugs and to monitor possible chemical changes during thermal demagnetisation experiments. A total of 46 specimens were measured (Table 2).

\section{Remanence}

The direction (declination and inclination) and intensity of the natural remanent magnetisation (NRM) was determined using a Molspin spinner magnetometer. The plugs with preferred dimensions of $2.2 \mathrm{~cm}$ in length and a diameter of $2.5 \mathrm{~cm}$ (plugs from the solid core) were all measured and demagnetised in detail, see below. The NRM of the sidewall cores was also measured but, due to the variable length of the core pieces, only one (SWC57) was investigated in detail (Table 2). The sensitivity of the Molspin spinner is $\pm 0.02 \mathrm{~mA} / \mathrm{m}$ and the direction of the remanence within the plug was determined to within $\pm 1^{\circ}$. The declination and inclination is given with respect to the local specimen coordinates, assuming the axis of the plug (= specimen) to be approximately horizontal (i.e. orthogonal to the Lopra-1/1A drill hole). As the azimuth of the vertical core is not known, the true magnetic decli- 
Table 2b. Lopra-1/1A: magnetic susceptibility, NRM, Q-ratio, density

Sidewall cores $(d=23.3 \mathrm{~mm})$

\begin{tabular}{|c|c|c|c|c|c|c|c|c|c|}
\hline $\begin{array}{l}\text { Sample } \\
\text { No. }\end{array}$ & $\begin{array}{l}\text { Depth } \\
\text { m }\end{array}$ & $\begin{array}{l}\text { Rock } \\
\text { type }\end{array}$ & $\begin{array}{c}\text { Weight } \\
\text { g }\end{array}$ & $\begin{array}{l}\text { Density } \\
\mathrm{g} / \mathrm{cm}^{3}\end{array}$ & $\begin{array}{l}\text { NRM } \\
\mathrm{mA} / \mathrm{m}\end{array}$ & $\begin{array}{l}\text { Suscept- } \\
\text { bridge } \\
10^{-3} \mathrm{SI}\end{array}$ & $\begin{array}{c}\text { High } \\
>2 \times 10^{-3} \\
10^{-3} \mathrm{SI}\end{array}$ & $\begin{array}{c}\text { Low } \\
<2 \times 10^{-3} \\
10^{-3} \mathrm{SI}\end{array}$ & $\begin{array}{c}\text { Q-ratio } \\
\mathrm{NRM} /(\mathrm{F} \times \text { Sus }\end{array}$ \\
\hline 59 & 2219.00 & basalt & 18.966 & 2.361 & 4406 & 1.43 & & 1.43 & 77.4 \\
\hline 57 & 2275.00 & basalt & 22.222 & 2.857 & 2180 & 87.96 & 87.96 & & 0.623 \\
\hline 46 & 2441.00 & basalt & 23.857 & 2.865 & 9027 & 46.65 & 46.65 & & 4.864 \\
\hline 44 & 2456.00 & basalt, ves. & 33.653 & 2.488 & & & & & \\
\hline 43 & 2475.00 & basalt, ves. & 18.421 & 1.981 & 0.7 & 0.55 & & 0.55 & 0.032 \\
\hline 40 & 2558.00 & basalt, ves. & 17.973 & 2.708 & 1.3 & 0.71 & & 0.71 & 0.046 \\
\hline 39 & 2559.80 & basalt, ves. & 22.920 & 2.711 & 1.5 & 0.64 & & 0.64 & 0.060 \\
\hline 38 & 2560.20 & tuff, lapilli & 21.428 & 2.336 & 0.4 & 0.61 & & 0.61 & 0.015 \\
\hline 37 & 2562.00 & tuff & 29.838 & 2.345 & & & & & \\
\hline 36 & 2570.00 & basalt & 9.353 & 2.379 & 38.5 & 0.69 & & 0.69 & 1.406 \\
\hline 34 & 2610.00 & basalt, alt. & 18.741 & 3.167 & 3412 & 69.17 & 69.17 & & 1.240 \\
\hline 33 & 2630.00 & tuff, lapilli & 13.720 & 2.404 & 587 & 1.60 & & 1.60 & 9.224 \\
\hline 31 & 2690.00 & tuf, lapilli & 8.082 & 2.276 & 365 & 1.83 & & 1.83 & 5.022 \\
\hline 30 & 2780.00 & basalt & 21.170 & 2.929 & 7171 & 76.89 & 76.89 & & 2.344 \\
\hline 26 & 2970.00 & tuf, lapilli & 18.744 & 2.553 & 304 & 3.77 & 3.77 & & 2.030 \\
\hline 25 & 3030.00 & basalt & 18.515 & 2.808 & 1146 & 26.67 & 26.67 & & 1.080 \\
\hline 19 & 3233.50 & tuff & 9.915 & 2.572 & & 0.72 & & 0.72 & \\
\hline 16 & 3328.00 & basalt & 18.471 & 2.875 & 106 & 1.13 & & 1.13 & 2.346 \\
\hline 15 & 3382.00 & basalt & 14.066 & 2.919 & & 63.36 & 63.36 & & \\
\hline 13 & 3438.00 & tuf, lapilli & 19.505 & 2.549 & 1.8 & 0.62 & & 0.62 & 0.074 \\
\hline 12 & 3464.50 & tuf, lapilli & 17.287 & 2.605 & 12.0 & 0.64 & & 0.64 & 0.470 \\
\hline 9 & 3500.50 & basalt & 16.494 & 3.001 & 0.8 & 0.83 & & 0.83 & 0.024 \\
\hline 6 & 3512.50 & tuff & 23.953 & 2.648 & 38.2 & 0.39 & & 0.39 & 2.433 \\
\hline 5 & 3514.50 & tuf, lapilli & 13.372 & 2.511 & & 0.58 & & 0.58 & \\
\hline 5 & 3514.50 & tuf, lapilli & 15.648 & 2.607 & & 0.58 & & 0.58 & \\
\hline 4 & 3531.00 & basalt & 27.341 & 2.940 & & 0.88 & & 0.88 & \\
\hline & b: & \multicolumn{2}{|l|}{ Mean } & 2.63 & 1516 & 16.20 & 34.47 & 0.85 & 1.85 \\
\hline & & \multicolumn{2}{|c|}{ Standard deviation } & 0.27 & 2585 & 28.80 & 21.00 & 0.39 & 2.34 \\
\hline & & \multicolumn{2}{|c|}{ Mean error } & 0.05 & 593 & 5.88 & 3.90 & 0.10 & 0.55 \\
\hline & & \multicolumn{2}{|l|}{$\mathrm{N}$} & 26 & 19 & 24 & 29 & 17 & $\left.18^{*}\right)$ \\
\hline & a \& b: & \multicolumn{2}{|c|}{ Mean } & 2.68 & 1895 & 22.1 & 34.5 & & 2.16 \\
\hline & & \multicolumn{2}{|c|}{ Standard deviation } & 0.27 & 3276 & 23.6 & 21.4 & & 2.45 \\
\hline & & \multicolumn{2}{|c|}{ Mean error } & 0.05 & 525 & 3.5 & 4.0 & & 0.40 \\
\hline & & \multicolumn{2}{|l|}{$\mathrm{N}$} & 32 & 39 & 46 & 29 & & $38 *)$ \\
\hline
\end{tabular}

*) Excluding sample No. 59

nation is not known. A further description of the palaeomagnetic experimental standard laboratory procedures may be found in e.g. Butler (1992).

\section{AF-demagnetisation}

After measuring the initial NRM intensity, 16 of the 20 plugs were AF-demagnetised in stepwise increasing alternating magnetic fields (Table 3) using a Molspin AF-demagnetiser. Minimum and maximum AF-fields were 2.5 $\mathrm{mT}(25 \mathrm{Oe})$ and $100 \mathrm{mT}$ (1000 Oe), respectively.

\section{Thermal demagnetisation}

Stepwise thermal demagnetisation was made in a Schonstedt furnace on four plugs from the solid core. An initially moderate AF-demagnetisation of up to between 7.5 and $15 \mathrm{mT}$ removed recently induced viscous magnetisation components, most likely acquired during the drilling operations (details in Table 2), after which the thermal demagnetisation was applied. 
Table 3. Lopra-1/1A: palaeomagnetic results

\begin{tabular}{|c|c|c|c|c|c|c|c|c|c|c|}
\hline \multirow[t]{2}{*}{$\begin{array}{l}\text { Sample } \\
\text { No. }\end{array}$} & \multirow[t]{2}{*}{$\begin{array}{l}\text { Depth } \\
\text { m }\end{array}$} & \multirow[t]{2}{*}{ Polarity } & \multirow[t]{2}{*}{$\begin{array}{l}\text { Weight } \\
g\end{array}$} & \multirow[t]{2}{*}{$\begin{array}{l}\text { Treatment } \\
\mathrm{AF} \mathrm{mT} /{ }^{\circ} \mathrm{C}\end{array}$} & \multirow{2}{*}{$\begin{array}{c}\text { NRM } \\
\text { intensity } \\
\mathrm{A} / \mathrm{m}\end{array}$} & \multicolumn{2}{|c|}{$\begin{array}{c}\text { Characteristic } \\
\text { direction }\end{array}$} & \multirow{2}{*}{$\begin{array}{c}\text { MAD } \\
\text { Degrees }\end{array}$} & \multicolumn{2}{|c|}{$\begin{array}{c}\text { Demag interval } \\
\text { AF thermal }\end{array}$} \\
\hline & & & & & & Decl (rel.) & Incl & & $\mathrm{mT}$ & $\begin{array}{l}\text { Tmax } \\
{ }^{\circ} \mathrm{C}\end{array}$ \\
\hline 1 & 2380.08 & $(? \mathrm{~N})$ & 31.79 & $0-40$ & 18.00 & 335 & 81 & 6 & $15-50$ & \\
\hline 2 & 2380.12 & $(? \mathrm{~N})$ & 28.66 & $0-40$ & 3.26 & 350 & 71 & 2 & $5-40$ & \\
\hline 3 & 2380.17 & $\mathrm{R}$ & 30.38 & $0-70$ & 0.33 & 358 & -70 & 2 & $15-70$ & \\
\hline 4 & 2380.21 & $\mathrm{R}$ & 28.78 & $0-7.5$ & 1.25 & 175 & -70 & 4 & & \\
\hline 5 & 2380.28 & $\mathrm{R}$ & 29.76 & $0-95$ & 0.67 & 345 & -69 & 1 & $10-95$ & \\
\hline 6 & 2380.58 & $\mathrm{R}$ & 28.22 & $0-40$ & 2.32 & 51 & -67 & 1 & $5-40$ & \\
\hline 7 & 2380.62 & $\mathrm{R}$ & 31.37 & $0-70$ & 2.55 & 62 & -71 & 1 & $5-70$ & \\
\hline 8 & 2380.66 & $\mathrm{R}$ & 26.24 & $0-40$ & 1.23 & 75 & -69 & 1 & $5-40$ & \\
\hline 9 & 2380.69 & $\mathrm{R}$ & 28.84 & $0-50$ & 1.39 & 80 & -71 & 1 & $5-50$ & T630 \\
\hline 10 & 2380.75 & $\mathrm{R}$ & 29.92 & $0-630$ & 0.97 & 289 & -75 & 3 & & \\
\hline 11 & 2380.79 & $\mathrm{R}$ & 27.21 & $0-50$ & 1.54 & 106 & -72 & 2 & $5-50$ & T600 \\
\hline 12 & 2380.91 & $\mathrm{R}$ & 29.37 & $0-600$ & 0.33 & 7 & -72 & 2 & & \\
\hline 13 & 2380.94 & $\mathrm{R}$ & 30.07 & $0-50$ & 1.78 & 169 & -70 & 2 & $5-50$ & \\
\hline 14 & 2380.97 & $\mathrm{R}$ & 27.08 & $0-40$ & 1.63 & 204 & -71 & 1 & $5-40$ & \\
\hline 15 & 2381.00 & $\mathrm{R}$ & 26.96 & $0-50$ & 0.98 & 195 & -70 & 2 & $5-50$ & T630 \\
\hline 16 & 2381.05 & $\mathrm{R}$ & 30.99 & $0-630$ & 0.36 & 334 & -74 & 2 & & \\
\hline 17 & 2381.09 & $\mathrm{R}$ & 29.11 & $0-70$ & 0.89 & 163 & -73 & 3 & $10-70$ & T630 \\
\hline 18 & 2381.12 & $\mathrm{R}$ & 30.24 & $0-630$ & 0.32 & 334 & -74 & 2 & & \\
\hline 19 & 2381.22 & $\mathrm{R}$ & 29.87 & $0-50$ & 2.62 & 32 & -73 & 3 & $5-50$ & \\
\hline 20 & 2381.25 & $\mathrm{R}$ & 25.87 & $0-50$ & 2.71 & 24 & -71 & 4 & $0-50$ & \\
\hline
\end{tabular}

\section{Results}

\section{Bulk density}

The bulk density of sidewall cores and plugs are listed in Table 2. The mean bulk density of the solid basaltic core was well-determined as $2.92 \pm 0.02$ (standard deviation $(\sigma)=0.05) \mathrm{g} / \mathrm{cm}^{3}$, although the determination was based on only six specimens. The bulk density of the SWC-cores was lower and much more scattered, $2.63 \pm 0.05(\sigma=0.27)$ $\mathrm{g} / \mathrm{cm}^{3}$. The low bulk density and high scatter is likely to be due to differences in porosity and the abundance of secondary minerals.

\section{Susceptibility}

The magnetic susceptibility is also listed in Table 2 and shown in Fig. 7. In contrast to for instance the bulk density, the magnetic susceptibility and remanence intensity may vary considerably, and they are known typically to be logarithmically normal distributed (e.g. Tarling 1983; Abrahamsen \& Nordgerd 1994). This is also the case here, as two log-normal distributions are found. The core susceptibility varies between 4 and $46 \times 10^{-3} \mathrm{SI}$, and the susceptibility of the SWC-cores varies even more, between 0.4 and $88 \times 10^{-3} \mathrm{SI}$. The data thus fall into two populations,

\begin{tabular}{|c|c|c|c|}
\hline Rev.: & Mean inclination & -71.22 & \\
\hline & Standard deviation & 1.99 & \\
\hline & $\mathrm{N}$ & 18 & \\
\hline \multirow[t]{3}{*}{ Norm: } & Mean inclination & 76.00 & \\
\hline & Standard deviation & 5 & \\
\hline & $\mathrm{N}$ & 2 & \\
\hline \multirow[t]{3}{*}{ All Rev: } & Mean inclination & -71.70 & \\
\hline & Standard deviation & 2.85 & $\alpha_{95}=1.95$ \\
\hline & $\mathrm{N}$ & 20 & $k=709$ \\
\hline
\end{tabular}

the limit between the two groups being about $2 \times 10^{-3} \mathrm{SI}$. The higher group yields an average susceptibility of $34 \pm 4$ $(\sigma=21) \times 10^{-3} \mathrm{SI}$ and the lower group an average susceptibility of $0.85 \pm 0.1(\sigma=0.39) \times 10^{-3} \mathrm{SI}$.

The more strongly magnetised group is represented mostly by unaltered basalts, whereas the less strongly magnetised group is more typical of most sediments including tuffaceous sediments, as well as vitrinites and deuterically altered or weathered basalts. In the present case the difference between high and low values in the basalts is likely to be caused by alterations of the primary Ti-magnetites, since Ti-magnetite is the main carrier of the remanence (see below).

\section{NRM intensity}

The intensity of the NRM (natural remanent magnetisation) is listed in Table 2 and shown in Fig. 7. Values of the 

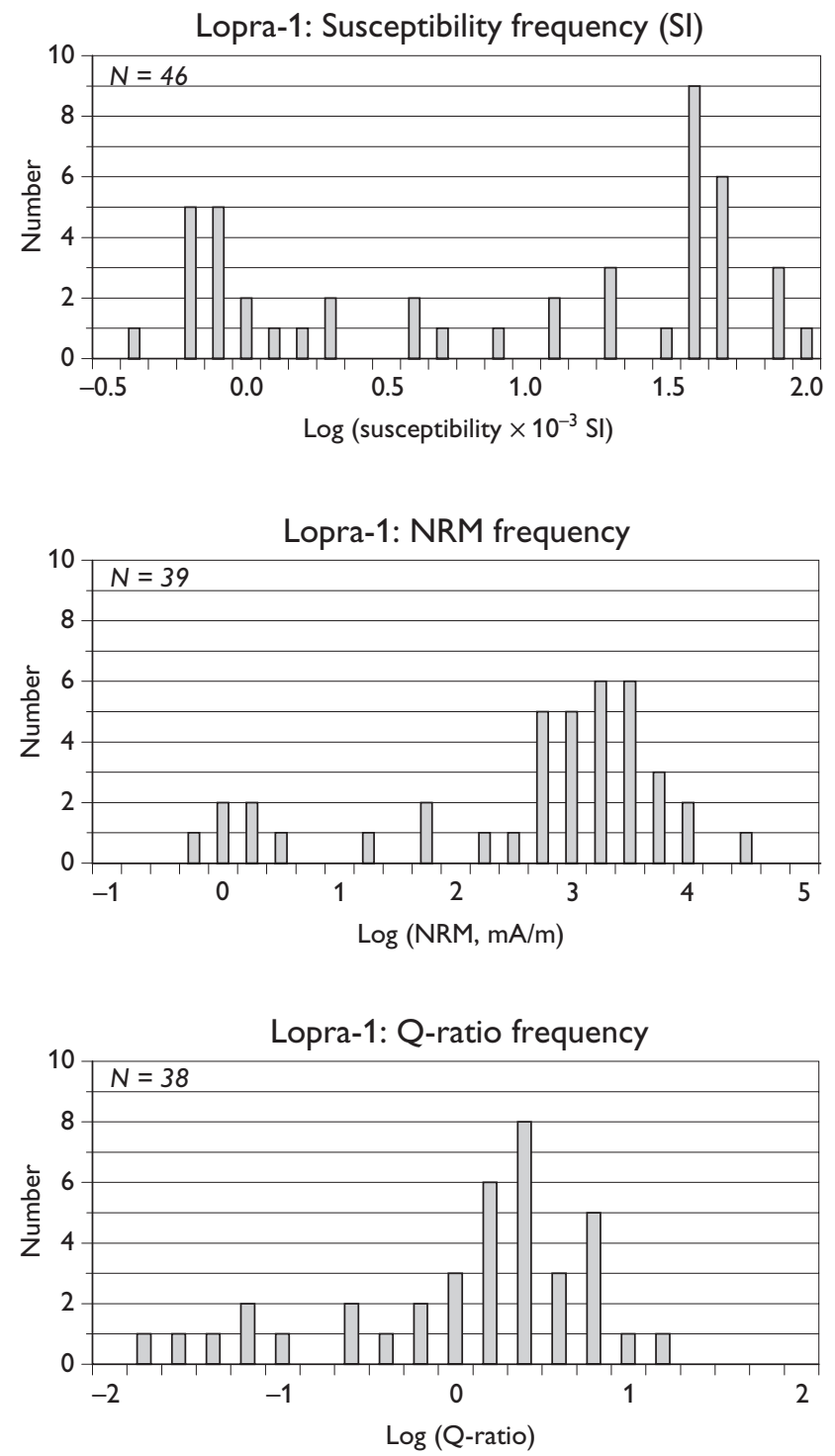

Fig. 7. Histograms of susceptibility, NRM intensity and Q-ratio. All appear bimodal on a logarithmic scale. order of $1 \mathrm{~A} / \mathrm{m}$ are typical for the unaltered basalts, whereas tuffs and altered basalts may have lower values. The mean NRM intensity value of the core plugs is $2.26 \pm 0.85(\sigma=$ 3.8) $\mathrm{A} / \mathrm{m}$, and the mean NRM intensity value of the SWCcores is $1.52 \pm 0.59(\sigma=2.6) \mathrm{A} / \mathrm{m}$. Due to the high scatter, the mean NRM intensities of the two groups are not significantly different. The combined populations plotted logarithmically (Fig. 9) again show two overlapping lognormal distributions, as do the susceptibilities (Fig. 8).

\section{Q-ratio}

The Q-ratio (Koenigsberger ratio) illustrated in Fig. 10 is the ratio between the remanent $\left(\mathrm{J}_{\mathrm{NRM}}\right)$ and the induced $\left(\mathrm{J}_{\mathrm{i}}=\right.$ $\mathrm{k} \cdot \mathrm{F})$ magnetisation, $\mathrm{Q}=\mathrm{J}_{\mathrm{NRM}} / \mathrm{J}_{\mathrm{i}}=\mathrm{J}_{\mathrm{NRM}} /(\mathrm{k} \cdot \mathrm{F}), \mathrm{F}$ being the intensity of the local geomagnetic field, $\mathrm{F} \approx 0.05 \mathrm{mT}$. For basaltic rocks, values between 0.2 and 10 are characteristic. Generally, the higher value the more fresh and unaltered the samples are. Mean values for $\mathrm{Q}$ is found to be $2.4 \pm 0.6(\sigma=2.5)$ for the core plugs, and $1.8 \pm 0.6(\sigma=$ 2.3) for the SWC-cores, respectively (omitting a single extraordinary high value of $\mathrm{Q}=77$ for SWC59). The Q-ratios of the two groups are not significantly different, but again the combined population has a tendency to two log-normal distributions.

\section{Magnetic carriers}

Two examples of isothermal remanent magnetisation (IRM) acquisition of plugs Nos 3 and 7 are shown in Fig. 11. Both specimens show magnetic saturation around 0.1 $\mathrm{T}$, which indicate that the dominant carrier of the remanence is magnetite or Ti-magnetite, although maghemite may also be present. The thermal demagnetisations (see below) show blocking temperatures between 560 and
Fig. 8. Magnetic susceptibility of sidewall cores (diamonds) and core plugs (dotted line shows extent), logarithmic scale.

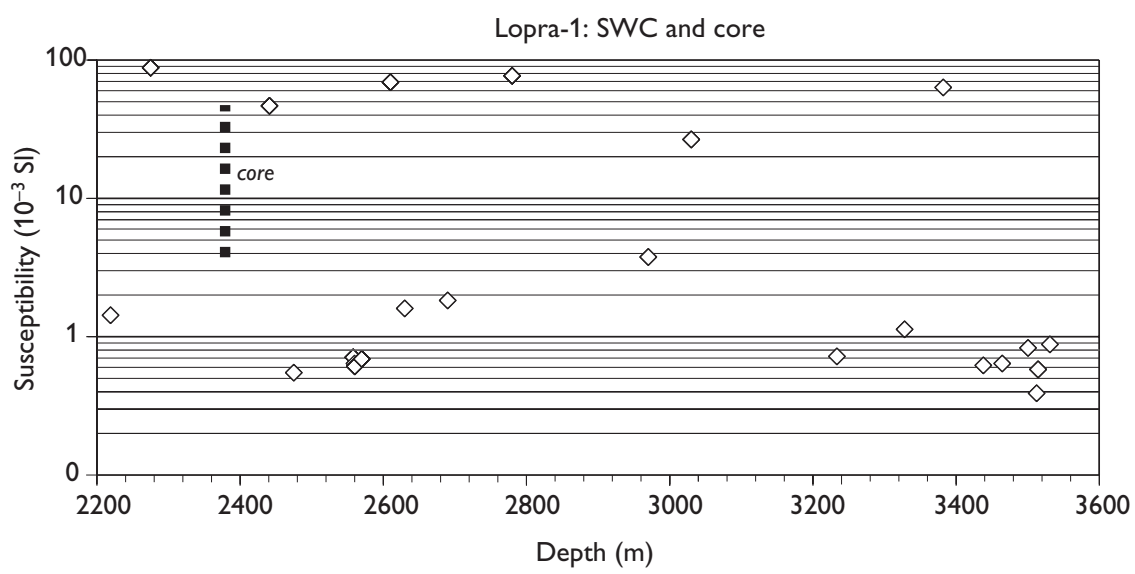




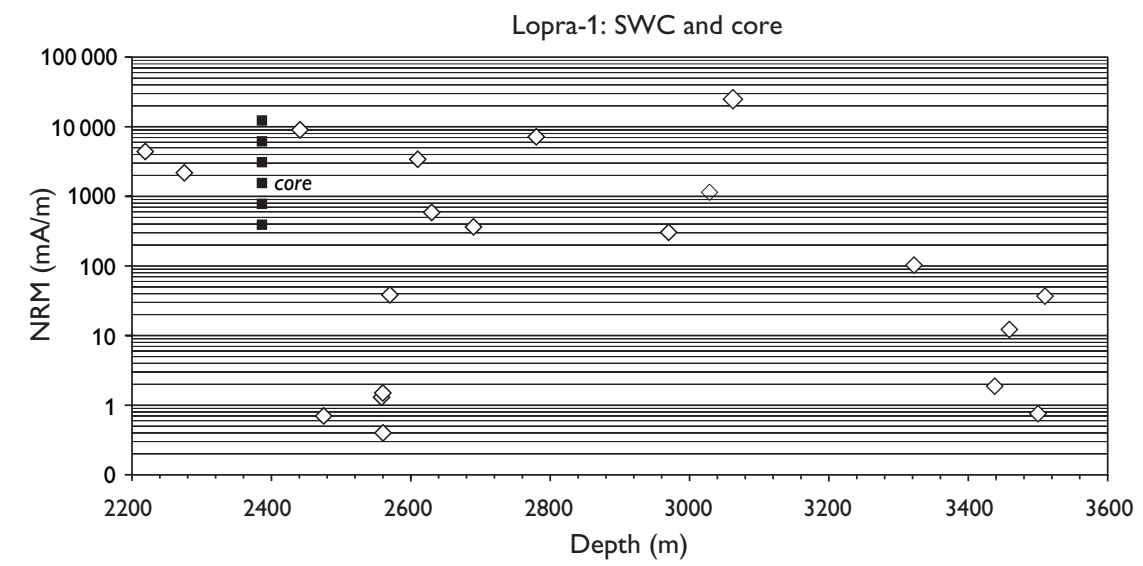

Fig. 9. NRM intensity of side-wall cores (diamonds) and core plugs (dotted line shows extent), logarithmic scale.

$580^{\circ} \mathrm{C}$, indicating that the Ti-content is low, pure magnetite having a Curie temperature of $580^{\circ} \mathrm{C}$ (e.g. Dunlop \& Özdemir 1997).

\section{AF and thermal demagnetisations}

The NRM values of the 20 cores and the SWC-cores are listed in Tables $2 \mathrm{a} \& \mathrm{~b}$, and examples of characteristic results of the $\mathrm{AF}$ and thermal demagnetisation experiments performed are illustrated in Fig. 12. Thermal demagnetisations were made on cores Nos 10,12, 16 and 18 and AF-demagnetisations were made on the remaining 16 cores. Values chosen for the AF-field were in most cases 0 , $5,7.5,10,15,20,25,30,40,50$ and $60 \mathrm{mT}$. Some plugs were further demagnetised to $70,80,90$ and $100 \mathrm{mT}$. Four thermally demagnetised plugs were first AF-demagnetised in $2.5,5,7.5$, and $10 \mathrm{mT}$ fields, to remove the recent drillstem-induced viscous remanence (see below), and then stepwise demagnetised at temperatures of 150 , $250,350,450,550,570,600$ and $630^{\circ} \mathrm{C}$.

The examples in Fig. 12 show stereographic plots (left) of the direction of the unit vector of the remanent mag- netisation (solid signature: positive inclination, open signature: negative inclination). All except the first example show characteristic stable negative inclinations. To the right, the corresponding intensity decay of the sample is shown (normalised to the initial value $\mathrm{J}_{0}=\mathrm{J}_{\mathrm{NRM}}$ ), the horizontal scale indicating the peak value of the applied alternating field in $\mathrm{Oe}(\times 0.1 \mathrm{mT})$, or the temperature in C.

\section{Inclination}

Prior to the demagnetisation experiments, about half of the plugs showed a low coercivity NRM with positive inclination (down-dip), which is most likely due to a drillstem induced viscous remanent magnetisation (VRM). The VRM was easily removed by AF-demagnetisation in low fields, typically between 2.5 and $5 \mathrm{mT}$.

Based upon the AF- and Thermal demagnetisation data, the characteristic (stable) remanent magnetisations for each plug were determined by the principal component analysis (PCA) method of Kirschvink (1980), as implemented in the IAPD-programme by Torsvik (1986). In all cases a stable characteristic, supposed primary, mag-

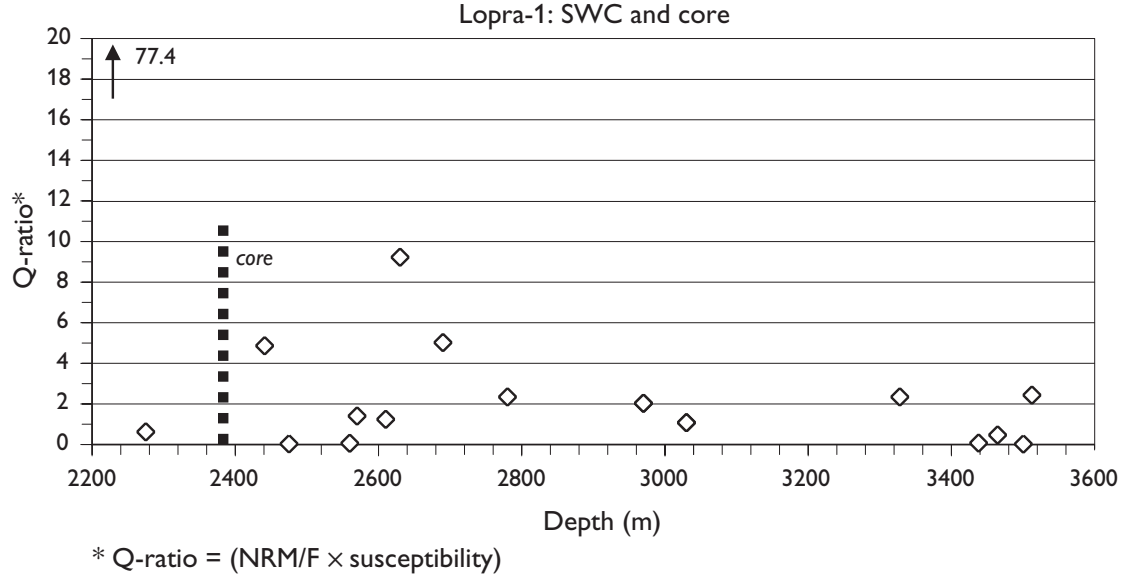

Fig. 10. Q-ratio of side-wall cores (diamonds) and core plugs (dotted line shows extent). 


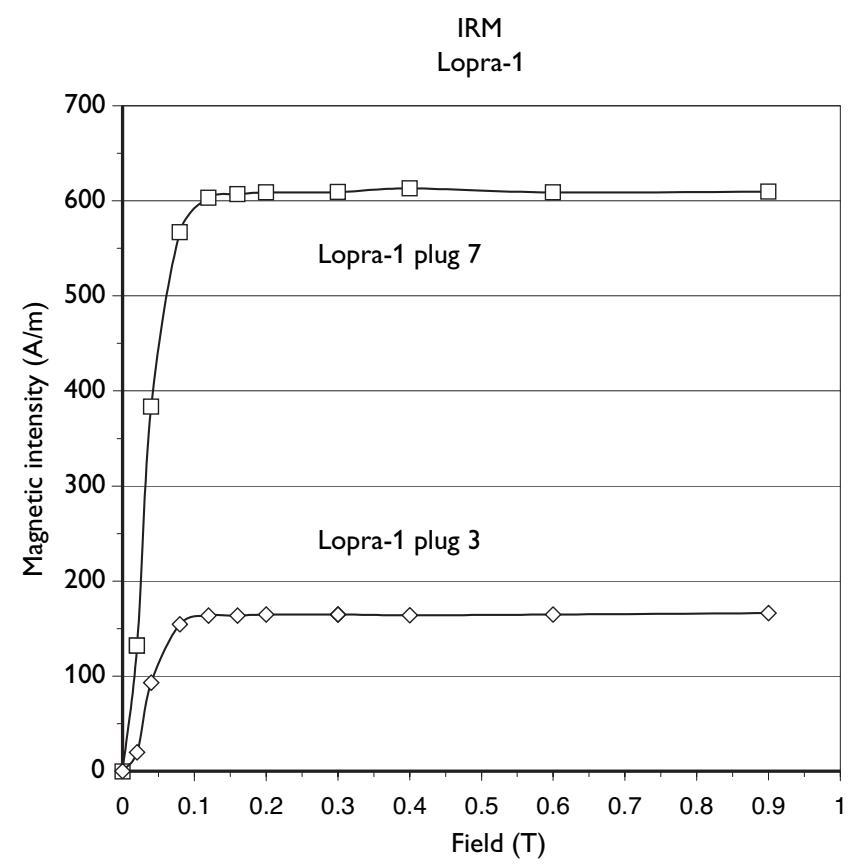

Fig. 11. Isothermal remanent magnetisation (IRM) of plugs Nos 3 and 7 . Both specimens show magnetic saturation around $0.1 \mathrm{~T}$, indicating that the dominating carrier of the remanent magnetisation is magnetite. netisation was isolated, as listed in Table 3, and illustrated in the stereogram of Fig. 13. (Bearing in mind that the azimuth of the core is not known, only the inclinations are diagnostic, declinations being relative.)

After cleaning, plugs Nos 3 to 20 show typical steep negative inclinations. Only plugs 1 and 2 show normal inclinations and they are both from the topmost $10 \mathrm{~cm}$ long core-piece. The broken core is from the massive centre of a very thick flow and it is most unlikely that the inclination should shift the sign within the core. It is therefore suggested that the top part of the core has been turned upside-down, most likely during the initial handling at the core site.

As the azimuth of the core is not known, ordinary Fisher statistics are not applicable, but the modified inclination statistics of Kono (1980) may be used. Supposing all 20 plugs to have negative inclinations, the mean value is found to be:

$$
I_{m}=-71.7^{\circ} \text {, with } \alpha_{95}=1.95^{\circ}(\mathrm{k}=709, \mathrm{~N}=20)
$$

provided that the drilling was truly vertical. This would give an unusually accurate determination of the palaeofield inclination. However, as the geomagnetic secular variation cannot be recorded from one flow only, this low value
Fig. 12. Examples of typical behaviour of samples during AF and thermal demagnetisation. Plugs Nos 2 (AF 0-40 mT), 3 (AF 0-70 $\mathrm{mT}$ ) and 10 (AF 0-10 mT, combined with heating up to $630^{\circ} \mathrm{C}$ ). Plugs Nos 14 (AF 0$40 \mathrm{mT}$ ), 18 (AF 0-10 mT, combined with heating up to $630^{\circ} \mathrm{C}$ ) and 20 (AF $0-50 \mathrm{mT}$ ).
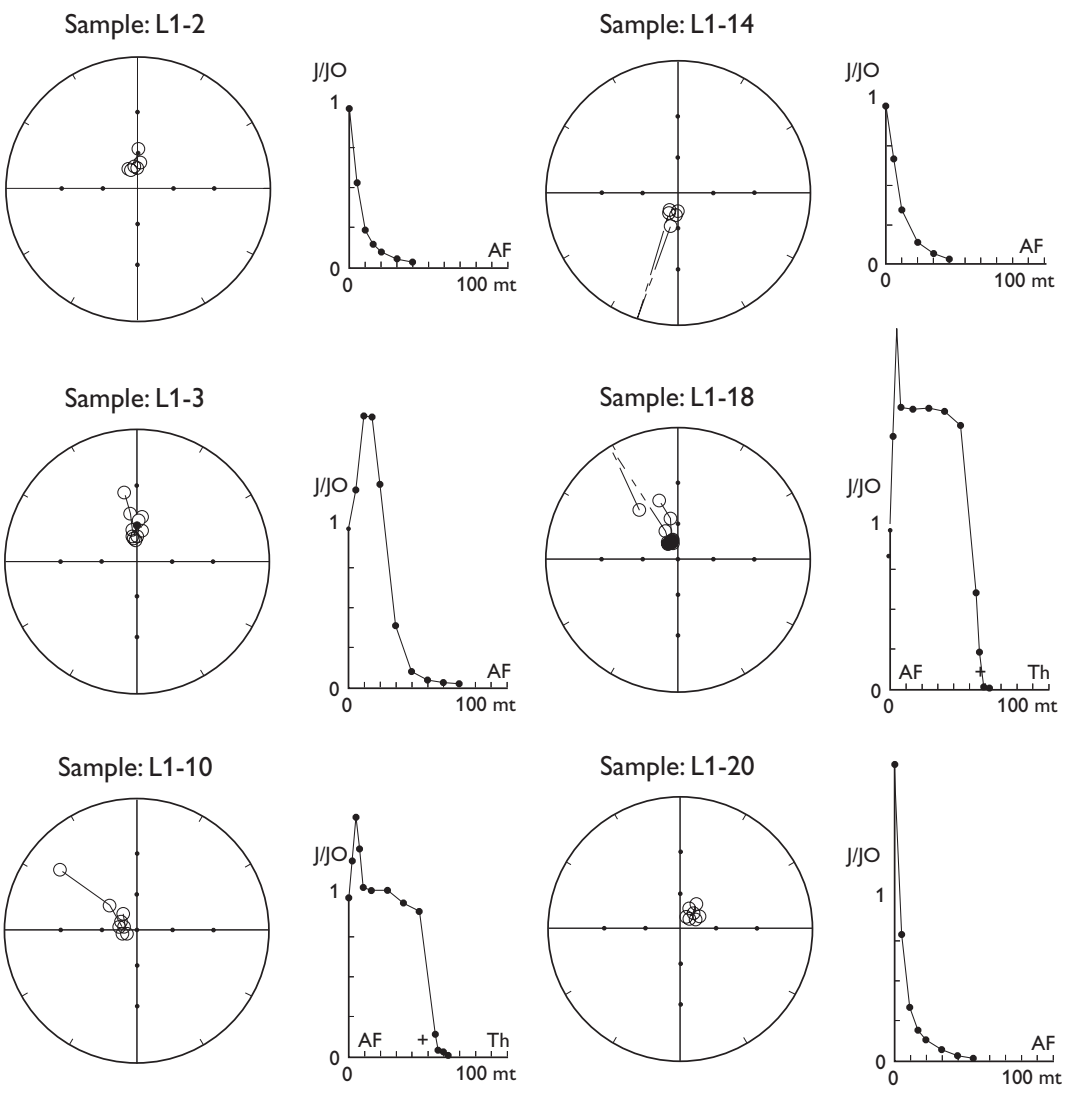


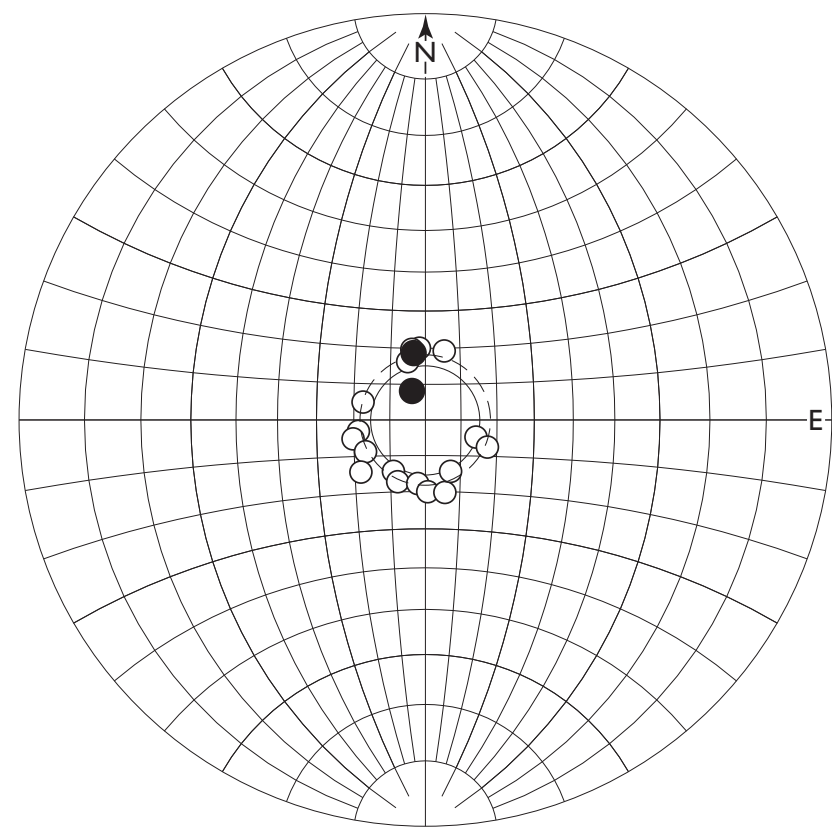

Fig. 13. Characteristic AF-cleaned inclinations of the 20 plugs from the Lopra-1/1A core at depths between 2380 and $2381.4 \mathrm{~m}$. Plugs other than Nos 1 and 2 (with positive inclinations, solid symbols) have negative inclinations (open symbols). The declinations are arbitrary since the azimuth of the core is not known. Full circle shows the expected axially centred dipole inclination of $74.7^{\circ}$ at the Lopra-1/1A drill site, i.e. $3^{\circ}$ steeper than the numerical average of $-71.7^{\circ}$ (dashed circle) of the 20 core plugs (See Table 1).

of $\alpha_{95}$ does not give a realistic estimate for the accuracy of the average palaeomagnetic field inclination. Furthermore an angle of $c .2 .5^{\circ}$ from the vertical towards the southeast has been obtained from the GHMT-log of the hole at $2380 \mathrm{~m}$ (R. Waagstein, personal communication 2005).

The inclination $\mathrm{I}_{0}$ of the geocentral axial dipole (GAD) field at the site of Lopra/Suðuroy with a latitude of $61.4^{\circ} \mathrm{N}$ is equivalent to a value of $\mathrm{I}_{0}=74.8^{\circ}$, which is about $3^{\circ}$ steeper than that found for the core. Based on McElhinny \& McFadden's (1997) analysis of a large number of volcanic data from the last $5 \mathrm{Ma}$ in the global palaeomagntic database, the expected geomagnetic dispersion of a VGP (virtual geomagnetic pole) at the latitude of the Faroe Islands may further be estimated to be $c .20^{\circ}$. Earlier palaeomagnetic investigations have typically given systematically lower mean values (see Figs 3, 5) for the palaeomagnetic inclination (Table 1) except the one of $-72^{\circ}$ for a site near Torshavn (Løvlie \& Kvingedal 1975). If we suppose the value from the Lopra-1/1A core of $I_{m}=-71.7^{\circ}$ to be the optimum one, this would correspond to an axial dipole palaeolatitude for the Lopra-1/1A site of $56.2^{\circ} \mathrm{N}$ at the time of extrusion. Most Cenozoic palaeopoles tend to be 'farsided' (Wilson 1971; Merrill et al. 1998), i.e. the palaeofield recorded in the rocks shows a more shallow inclination than does the present-day geomagnetic field at the site and biased shallow inclinations are also the case for most of the Palaeogene volcanic palaeomagnetic data from the North Atlantic region. This phenomenon may be due either to northward plate tectonic movements after the formation of the sample, non-symmetric behaviour of the geomagnetic field at the time of formation or unusual magnetic properties of the rocks investigated or a combination of all three effects. A systematic error due to the latter cause (magnetic refraction) is not likely, as this requires rather strong values of the magnetic properties of the lavas (e.g. Knudsen et al. 2003). If the palaeogeomagnetic field was exactly a geocentral axial dipole field (the GAD-hypothesis), this would imply that the lithospheric plate carrying the Faroe Islands had moved about $5.2^{\circ}$ northward during the last $c .60 \mathrm{Ma}$ with an average northward component of velocity of $c .1 \mathrm{~cm} /$ year. An octopole contribution of the order of $10 \%$ (i.e. $\mathrm{g}_{3}{ }^{\circ} / \mathrm{g}_{1}{ }^{\circ}=$ 0.1 ) to the central axial dipole field would alone suffice to explain the observed farsidedness of the Faroe Islands. An octopole contribution of this order of magnitude has been considered for Precambrian and Palaeozoic as well as Mesozoic times (e.g. Kent \& Smethurst 1998; Torsvik et al. 2001; Van der Voo \& Torsvik 2001). However, Merrill \& McFadden's (2003) analysis of data in the palaeomagnetic global database for the last $5 \mathrm{Ma}$ concluded that a nondipole bias appears less likely for the younger periods.

Therefore, rather than claming that the shallower value of inclination indicates fully either a northward plate movement of $5.2^{\circ}$ (the 'traditional' palaeomagnetic interpretation), or is due entirely to a deficiency in the GADhypothesis, a more cautious interpretation may be a combination of both, implying that the GAD-hypothesis may not be exactly valid for the early Palaeogene, i.e. that the palaeomagnetic field was not a perfect central and axial dipole field at that time. To solve this palaeomagnetic important question fully, more global data from the period is needed.

\section{Reversal stratigraphy and age at Lopra-1/1A}

As mentioned above, the reversal stratigraphy of the $6 \frac{1}{2}$ $\mathrm{km}$ thick Faroe basalt formations was re-interpreted by Waagstein (1988), based upon published data then available (Abrahamsen 1967; Tarling \& Gale 1968; Schönharting \& Abrahamsen 1984; Abrahamsen et al. 1984), including the former palaeomagnetic results from Lopra- 
1 , the cored information of which at that time reached a depth of $2178 \mathrm{~m}$. All five cores from Lopra-1, at depths of $338,862,1219,1923$ and $2178 \mathrm{~m}$, showed negative inclinations, i.e. reversed polarity, although no stable values were obtained after demagnetising the cores from 338 and $1219 \mathrm{~m}$ (Schönharting \& Abrahamsen 1984). The bottom of Lopra-1 was interpreted by Waagstein (1988) to match marine anomaly 26 r, thus superseding two earlier alternative correlations discussed by Abrahamsen et al. (1984), in which this level was suggested to match either marine anomaly $25 \mathrm{r}$ or $24 \mathrm{r}$.

The present data from Lopra-1/1A, with negative inclinations in the single core from $2380 \mathrm{~m}$ depth, indicates a reversed polarity at this level. Provided that there are no reversals in the unsampled interval above, the present data extend the reversed sequence of the lower basalt formation from the core at TD of the original well $(2178 \mathrm{~m})$ to the present level of the solid core at $2380 \mathrm{~m}$. The SWCcores reach the deeper level of $3531 \mathrm{~m}$. However, as the up-down orientation of the individual SWC-cores is not known, no inclination information has yet been obtained from below $2381 \mathrm{~m}$.

Combining all polarity evidence available from the Faroe Islands and comparing with the Paleocene time scale by Berggren et al. (2000), we conclude that the lower part (below sea level) of the lower basalt formation may be correlated with Chron C26r (Selandian age), while the upper (exposed) part of the lower basalt formation correlates with Chrons C26n, C25r and C25n (Selandian and Thanetian age). The middle and upper basalt formations correlate with Chron C24r (Ypresian age).

Magnetic logging (magnetic susceptibility and field intensity) was also attempted in the Lopra-1/1A well together with other geophysical logs (Boldreel 2006, this volume) but, due to technical problems with the magnetic logging tool, no reliable inclination data were obtained (Abrahamsen \& Waagstein 2006, this volume).

\section{Summary and conclusions}

A compilation of the palaeomagnetic age, the reversal chronology and evolution of the $c .61 / 2 \mathrm{~km}$ thick basalt formations of the Faroe Islands is presented, together with new petrophysical results from the Lopra-1/1A well.

1. The polarity record of the Faroe Islands has been correlated in detail with the Global Polarity Time Scale. The lower part (below sea level) of the lower basalt formation correlates with Chron C26r (Selandian age).The upper (exposed) part of the lower basalt for- mation correlates with Chrons C26n, C25r and C25n (Selandian and Thanetian age). The middle and upper basalt formations correlate with Chron C24r (Ypresian age).

2. The inclinations yield farsided positions for the palaeomagnetic poles, which is characteristic of most Palaeogene volcanics and sediments from the North Atlantic region.

3. The density and the rock magnetic properties of a solid core (1 $1 \frac{1}{2} \mathrm{~m}$ in length) and 26 sidewall cores from the Lopra-1/1A well between -2219 and $-3531 \mathrm{~m}$ are bimodal and suggest two characteristic groups of volcanic materials, solid unaltered basalts and altered basalts and tuffs.

4. The magnetic properties are typically log-normally distributed and the carriers of remanence appear to be Ti-poor Ti-magnetites with Curie temperatures close to $580^{\circ} \mathrm{C}$.

5. The inclination of the $1 \frac{1 / 2}{\mathrm{~m}}$ core at $-2380 \mathrm{~m}$ is predominantly negative.

6. Magnetic logging of magnetic susceptibility and field intensity was made in Lopra-1/1A down to $-3515 \mathrm{~m}$ together with other geophysical logging, but yielded inconclusive inclinations.

\section{Acknowledgements}

The rock and palaeomagnetic measurements were made in the Geophysical Laboratory of the Department of Earth Sciences, University of Aarhus. Informative discussions with Regin Waagstein and the access to material from the Lopra-1/1A well at GEUS are acknowledged. Suggestions for improvements of the manuscript from Regin Waagstein, John Piper, the editor and an anonymous referee are also acknowledged.

\section{References}

Abrahamsen, N. 1965: Geofysiske undersøgelser på Færøerne, 144 pp. Unpublished cand. scient. thesis, Aarhus Universitet, Danmark.

Abrahamsen, N. 1967: Some palaeomagnetic investigations in the Faeroe Islands. Bulletin of the Geological Society of Denmark 17, 371-384.

Abrahamsen, N. \& Nordgerd, P. 1994: Rock magnetism of Tertiary volcanics from North-East Greenland. Rapport Grønlands Geologiske Undersøgelse 162, 195-200.

Abrahamsen, N. \& Waagstein, R. 2006: Magnetic logs from the Lopra-1/1A and Vestmanna-1 wells, Faroe Islands. Geological 
Survey of Denmark and Greenland Bulletin 9, 41-49 (this volume).

Abrahamsen, N., Schönharting, G. \& Heinesen, M. 1984: Palaeomagnetism of the Vestmanna- 1 core and magnetic age and evolution of the Faeroe Islands. In: Berthelsen, O., Noe-Nygaard, A. \& Rasmussen, J. (eds): The Deep Drilling Project 1980-81 in the Faeroe Islands. Annales Societatis Scientiarum Faeroensis, Supplementum IX, 93-108. Tórshavn: Føroya Fróðskaparfelag.

Balling, N., Kristiansen, J.I. \& Saxov, S. 1984: Geothermal measurements from the Vestmanna-1 and Lopra-1 boreholes. In: Berthelsen, O., Noe-Nygaard, A. \& Rasmussen, J. (eds): The Deep Drilling Project 1980-81 in the Faeroe Islands. Annales Societatis Scientiarum Faeroensis, Supplementum IX, 137-147. Tórshavn: Føroya Fróðskaparfelag.

Balling, N., Breiner, N. \& Waagstein, R. 2006: Thermal structure of the deep Lopra-1/1A borehole in the Faroe Islands. Geological Survey of Denmark and Greenland Bulletin 9, 91-107 (this volume).

Berggren, W.A., Aubry, M.-P., van Fossen, M., Kent, D.V., Norris, R.D. \& Quillévéré, F. 2000: Integrated Paleocene calcareous plankton magnetobiochronology and stable isotope stratigraphy: DSDP Site 384 (NW Atlantic Ocean). Palaeogeography, Palaeoclimatology, Palaeoecology 159, 1-51.

Boldreel, L.O. 2006: Wire-line log-based stratigraphy of flood basalts from the Lopra-1/1A well, Faroe Islands. Geological Survey of Denmark and Greenland Bulletin 9, 7-22 (this volume).

Bott, M.H.P., Sunderland, J., Smith, P.J., Casten, U. \& Saxov, S. 1974: Evidence for continental crust beneath the Faeroe Islands. Nature 248, 202-204.

Bott, M.H.P., Nielsen, P.H. \& Sunderland, J. 1976: Continental $\mathrm{P}$-waves originating at the continental margin between the Iceland-Faeroe Ridge and the Faeroe Block. Geophysical Journal of the Royal Astronomical Society 44, 229-238.

Bullard, E.C., Everett, J.E. \& Smith, A.G. 1965: The fit of the continents around the Atlantic. Philosophical Transactions of the Royal Society of London A243, 67-92.

Burke, K. \& Torsvik, T.H. 2004: Derivation of Large Igneous Provinces of the past 200 million years from long-term heterogeneities in the deep mantle. Earth and Planetary Science Letters 227, 531-538.

Butler, R.F. 1992: Paleomagnetism: magnetic domains to geologic terranes, 319 pp. Boston: Blackwell Scientific Publications.

Casten, U. 1974: Eine Analyse seismischer Registrierungen von den Färöer Inseln. Hamburger Geophysikalische Einzelschriften, Geophysikalische Institut der Universität Hamburg 21, 109 pp.

Chambers, L.M., Pringle, M.S. \& Parrish, R.R. 2005: Rapid formation of the Small Isles Tertiary centre constrained by precise ${ }^{40} \mathrm{Ar} /{ }^{39} \mathrm{Ar}$ and U-Pb ages. Lithos 79, 367-384.

Dunlop, D.J. \& Özdemir, Ö. 1997: Rock magnetism: fundamentals and frontiers, 595 pp. Cambridge: University Press.

Kent, D.V. \& Smethurst, M.A. 1998: Shallow bias of palaeomagnetic inclinations in the Palaeozoic and Precambrian. Earth and Planetary Science Letters 160, 391-402.
Kirschvink, J. 1980: The least squares line and plane and the analysis of palaeomagnetic data. Geophysical Journal of the Royal Astronomical Society 62, 699-718.

Knott, S.D., Burchell, M.T., Jolley, E.J. \& Fraser, A.J. 1993: Mesozoic to Cenozoic plate reconstructions of the North Atlantic and hydrocarbon plays of the Atlantic margins. In: Parker, J.R. (ed.): Petroleum geology of Northwest Europe: Proceedings of the 4th Conference, 953-974. London: Geological Society.

Knudsen, M.F., Jacobsen, B.H. \& Abrahamsen, N. 2003: Palaeomagnetic distortion modelling and possible recovery by inversion. Physics of the Earth and Planetary Interiors 135, 55-73.

Kono, M. 1980: Statistics of paleomagnetic inclination data. Journal of Geophysical Research 85, 3878-3882.

Larsen, H.C. \& Saunders, A.D. 1998: Tectonism and volcanism at the southeast Greenland rifted margin: a record of plume impact and later continental rupture. In: Saunders, A.D., Larsen, H.C. \& Wise, S.W.J. (eds): Proceedings of the Ocean Drilling Program, Scientific Results 152, 503-533. College Station, Texas (Ocean Drilling Program).

Larsen, H.C., Brooks, C.K., Hopper, J.R., Dahl-Jensen, T., Pedersen, A.K., Nielsen, T.F.D. \& field parties 1995: The Tertiary opening of the North Atlantic: DLC investigations along the east coast of Greenland. Rapport Grønlands Geologiske Undersøgelse 165, 106-115.

Larsen, L.M., Waagstein, R., Pedersen, A.K. \& Storey, M. 1999: Trans-Atlantic correlation of the Palaeogene volcanic successions in the Faeroe Islands and East Greenland. Journal of the Geological Society (London) 156, 1081-1095.

Larsen, T.B., Yuen, D.A. \& Storey, M. 1999: Ultrafast mantle plumes and implications for flood basalt volcanism in the Northern Atlantic Region. Tectonophysics 311, 31-43.

Lawver, L.A. \& Muller, R.D. 1994: Iceland hotspot track. Geology 22, 311-314.

Løvlie, R. 1975: The oxidation state of some Tertiary rocks from the Faeroe Islands and its implications for palaeomagnetism. Geophysical Journal of the Royal Astronomical Society 40, 55-65.

Løvlie, R. \& Kvingedal, M. 1975: A palaeomagnetic discordance between a lava sequence and an associated interbasaltic horizon from the Faeroe Islands. Geophysical Journal of the Royal Astronomical Society 40, 45-54.

McElhinny, M.W. \& McFadden, P.L. 1997: Palaeosecular variation over the past 5 Myr based on a new generalized database. Geophysical Journal International 131, 240-252.

Merrill, R.T. \& McFadden, P.L. 2003: The geomagnetic axial dipole field assumption. Physics of the Earth and Planetary Interiors $139,171-185$.

Merrill, R.T., McElhinny, M.W. \& McFadden, P.L. 1998: The magnetic field of the Earth, 527 pp. London: Academic Press.

Mosar, J., Eide, E.A., Osmundsen, P.T., Sommaruga, A. \& Torsvik, T.H. 2002: Greenland-Norway separation: a geodynamic model for the North Atlantic. Norwegian Journal of Geology 82, 281-298.

Nielsen, P.H. 1976: Seismic refraction measurements around the Faeroe Islands. Frodskaparrit 24, 9-45. 
Nielsen, P.H., Waagstein, R., Rasmussen, J. \& Larsen, B. 1981: Marine seismicinvestigation of the shelf around the Faroe Islands. Danmarks Geologiske Undersøgelse Årbog 1981, 101-109.

Nielsen, P.H., Stefansson, V. \& Tulinius, H. 1984: Geophysical logs from Lopra-1 and Vestmanna-1. In: Berthelsen, O., NoeNygaard, A. \& Rasmussen, J. (eds): The Deep Drilling Project 1980-81 in the Faeroe Islands. Annales Societatis Scientiarum Faeroensis, Supplementum IX, 115-135. Tórshavn: Føroya Fróðskaparfelag.

Nielsen, T.K., Larsen, H.C. \& Hopper, J.R. 2002: Contrasting rifted margin styles south of Greenland: implications for mantle plume dynamics. Earth and Planetary Science Letters 200, 271-286.

Noe-Nygaard, A. \& Rasmussen, J. 1984: Introduction: Geological review and choice of drilling sites. In: Berthelsen, O., Noe-Nygaard, A. \& Rasmussen, J. (eds): The Deep Drilling Project 1980-81 in the Faeroe Islands. Annales Societatis Scientiarum Faeroensis, Supplementum IX, 9-13. Tórshavn: Føroya Fróðskaparfelag.

O’Connor, J.M., Stoffers, P., Wijbrans, J.R., Shannon, P.M. \& Morrissey, T. 2000: Evidence from episodic seamount volcanism for pulsing of the Iceland plume in the past 70 Myr. Nature 408, 954-958.

Ogg, J.C. 1995: Magnetic polarity time scale of the Phanerozoic. Ahrens, T.J. (ed.): Global earth physics: a handbook of physical constants, 240-270. Washington D.C: American Geophysical Union.

Pálmason, G. 1965: Seismic refraction measurements of the basalt lavas of the Faeroe Islands. Tectonophysics 2, 475-482.

Rasmussen, J. \& Noe-Nygaard, A. 1969: Beskrivelse til geologisk kort over Færøerne i målestok 1:50 000. Danmarks Geologiske Undersøgelse I. Række 24, 370 pp. + map vol. (with summaries in Faroese and English).

Rasmussen, J. \& Noe-Nygaard, A. 1970: Geology of the Faeroe Islands. Danmarks Geologiske Undersøgelse I. Række 25, 142 pp.

Richardson, K.R., Smallwood, J.R., White, R.S., Snyder, D.B. \& Maguire, P.K.H. 1998: Crustal structure beneath the Faeroe Islands and the Faeroe-Iceland Ridge. Tectonophysics 300, 159 180.

Riisager, P., Riisager, J., Abrahamsen, N. \& Waagstein, R. 2002a: New paleomagnetic pole and magnetostratigraphy of Faroe Islands flood volcanics, North Atlantic igneous province. Earth and Planetary Science Letters 201, 261-276.

Riisager, P., Riisager, J., Abrahamsen, N. \& Waagstein, R. 2002b: Thellier palaeointensity experiments on Faroes flood basalts: technical aspects and geomagnetic implications. Physics of the Earth and Planetary Interiors 131, 91-100.

Saxov, S. 1969: Gravimetry in the Faeroe Islands. Geodætisk Institut Meddelelse 43, $24 \mathrm{pp}$.

Saxov, S. \& Abrahamsen, N. 1964: A note on some gravity and density measurings in the Faeroe Islands. Bollettino di Geofisica, Teorica ed Applicata VI, 49-62.

Saxov, S. \& Abrahamsen, N. 1966: Some geophysical investigations in the Faeroe Islands. Zeitschrift für Geophysik 32, 455471.

Schönharting, G. \& Abrahamsen, N. 1984: Magnetic investigations on cores from the Lopra-1 drillhole, Faeroe Islands. In: Berthelsen, O., Noe-Nygaard, A. \& Rasmussen, J. (eds): The Deep Drilling Project 1980-81 in the Faeroe Islands. Annales Societatis Scientiarum Faeroensis, Supplementum IX, 109-114. Tórshavn: Føroya Fróðskaparfelag.

Schrøder, N.F. 1971: Magnetic anomalies around the Faeroe Islands. Fródskaparrit 19, 20-29. Tórshavn: Føroya Fróðskaparfelag.

Storey, M., Duncan, R.A., Larsen, H.C., Waagstein, R., Larsen, L.M., Tegner, C. \& Lesher, C.E. 1996: Impact and rapid flow of the Iceland plume beneath Greenland at $61 \mathrm{Ma}$. Eos, Transactions, American Geophysical Union 77, 839 only.

Tarling, D.H. 1970: Palaeomagnetic results from the Faeroe Islands. In: Runcorn, S.K. (ed.): Palaeogeophysics, 193-208. London: Academic Press.

Tarling, D.H. 1983: Palaeomagnetism, 379 pp. London: Chapman \& Hall.

Tarling, D.H. \& Gale, N.H. 1968: Isotopic dating and palaeomagnetic polarity in the Faeroe Islands. Nature 218, 1043-1044.

Tarling, D.H., Hailwood, E.A. \& Løvlie, R. 1988: A palaeomagnetic study of lower Tertiary lavas in E Greenland and comparison with other lower Tertiary observations in the northern Atlantic. In: Morton, A.C. \& Parson, L.M. (eds): Early Tertiary volcanism and the opening of the NE Atlantic. Geological Society Special Publication (London) 39, 215-224.

Torsvik, T. 1986: Interactive analysis of palaeomagnetic data. IAPD user-guide, 74 pp. Bergen: Universitetet i Bergen.

Torsvik, T., Van der Voo, R., Meert, J.G., Mosar, J. \& Walderhaug, H. 2001: Reconstructions of the continents around the North Atlantic at about the 60th parallel. Earth and Planetary Science Letters 187, 55-69.

Van der Voo, R. \& Torsvik, T. 2001: Evidence for late Paleozoic and Mesozoic non-dipole fields provides an explanation for the Pangea reconstruction problems. Earth and Planetary Science Letters 187, 71-81.

Waagstein, R. 1988: Structure, composition and age of the Faeroe basalt plateau. In: Morton, A.C. \& Parson, L.M. (eds): Early Tertiary volcanism and the opening of the NE Atlantic. Geological Society Special Publication (London) 39, 225-238.

Wilson, R.L. 1971: Dipole offset - the time average palaeomagnetic field over the past 25 million years. Geophysical Journal of the Royal Astronomical Society 22, 491-504.

Ziegler, P.A. 1990: Geological atlas of western and central Europe. Amsterdam: Elsevier. 